\title{
Progress Towards Democratic Policing
}

\section{Introduction}

Previous COMSA reports began to address aspects of the police role and functions in a democratic society and identified several challenges faced by the South African Police (SAP) in transforming itself from a force to a service. We focused primarily on the importance of building confidence and trust of communities in their local police in order to move towards policing by consent.

The first COMSA Report noted that the following values and attributes underpin democratic policing services:

- $\quad$ service not force

- fair and non-discriminatory service delivery

- care and compassion

- showing professional and ethical behaviour

- $\quad$ support for victims

- willingness to admit mistakes and learn from them

- minimal use of force

- openness to change

- a visible, reassuring presence

- accountability

- a prompt service.

In past reports, we measured actual police practices against these yardsticks and commented on many shortcomings including: the use of lethal force; unprofessional investigative techniques; partisan policing; the use of torture to obtain confessions; double standards and mixed messages especially where police agreements with local people are contradicted by the intervention and behaviour of the Internal Stability Unit (ISU), the SAP's public order division.

COMSA has continued its close consultations with the SAP through:

- talks and lectures to police community relations officers and at training colleges of the SAP;

- a presentation to the ANC Youth League on community policing; 
- interaction with the police community relations subcommittees of both regional and local peace committees;

- attendance at community policing seminars;

- a visit to the ISU training base and discussions with those in charge of the curriculum;

- continued contact with the Police Board set up under the National Peace Accord;

- contact and discussion with academics at the University of the Western Cape, University of South Africa (UNISA) and the University of Witwatersrand involved in research on a new South African police force.

From these contacts, we are assured that the SAP has begun the transformation from a force to a service, symbolised by the change of name to the South African Police Service in the Interim Constitution.

There is still scope for ensuring that the culture change is not simply cosmetic. For this to happen, the service ethos must permeate the entire organisation from top management to the grassroots level. This will involve a comprehensive review of the structure of the organisation and the extent to which it supports open, participative, fair and accountable practices.

\section{Progress towards Community Policing}

When the SAP created a community relations division on 1 December 1992, the chasm between police and communities was so vast that many critics questioned the feasibility of applying any model of community policing to South Africa.

Under the circumstances, COMSA is heartened by the commitment to change among officers from this division, exemplified by the dramatic increase in the number of local police/community forums where lively dialogue is taking place between police and communities.

COMSA has welcomed the opportunity to be part of this process by providing advice and guidance both at the police academy and police colleges as well as to police/community forums.

Several challenges still remain:

- There are still many parts of the country where old enmities endure and where much remains to be done to improve communication between the police and community.

An example is the declaration of unrest areas in the East Rand without consulting local forums which we mentioned in Chapter 4 . This undermines the forums and suggests that police may pick and choose which issues to share with local communities.

Another example is the patchiness with which accredited visitor schemes are being introduced despite local agreements and support for 
this practice of allowing lay persons to visit police cells and places of detention. This has raised questions over the commitment of the SAP to the scheme.

- Although the community relations division is an example of positive leadership in this field, there are some police divisions and individual senior officers who do not appear to have embraced the changes. It is essential under a democratic police service that all officers understand and practise the new principles of service delivery in their day to day work.

- Better relations between the police and community can only be developed if communities play an active part. COMSA will continue to support initiatives to assist communities to develop their own agendas for local policing so as to ensure that their priorities are reflected in police planning.

\section{Provisions for Community Policing in the Interim Constitution}

The Interim Constitution - when it comes into force after the elections - will require the SAP to establish community police forums at police station level. The functions of these forums will include:

- the promotion of local accountability;

- the monitoring of the effectiveness and efficiency of the service;

- advising the Service on local policing priorities;

- the evaluation of the provision of visible police services including siting and staffing of police stations, investigation of complaints, provision of protective services at demonstrations, patrolling and prosecution of offenders;

- requesting enquiries into policing matters in the locality.

The introduction in the Interim Constitution of an independent complaints investigative body under civilian control to oversee complaints against the police is a further example of a desire to enhance public confidence in the police and extend the principle of openness to third party scrutiny.

This role has, in the interim, to some extent been performed by the Police Reporting Officers established under the National Peace Accord whom we mention in Chapter 4.

\section{Structure of the SAP}

COMSA welcomes the provision in the Interim Constitution for National and Provincial Commissioners of Police. For community policing to succeed, it is essential that power be devolved from the centre to provincial and local level.

An example of where such authority is essential is the prevention of 
central units entering station areas without approval of the local commander, so destroying hard won local agreements on policing practice.

This obstacle to effective police/community relations has been noted in previous COMSA reports, and the issue now been taken up by all station commanders and community forums that COMSA has had contact with. It is vital that the problem of autonomous central units being licensed to disrupt harmonious police/community relations be addressed immediately.

The current six separate divisions of the SAP with their own reporting structures inhibits clear lines of communication and the development of a shared vision. It is hoped that under the new legislation, these structures will be co-ordinated at least at regional level, to remove this hindrance to efficient policing.

It is also hoped that the change to a service will be accompanied by a reduction in the number of ranks and the demilitarisation of the rank structure.

\section{Composition of the Police Service}

Previous COMSA reports have noted the under-representation of women and blacks within the SAP.

Women are poorly represented at all levels of the police establishment and are currently discriminated against in several ways, including terms and conditions of service and placement within the organisation in secretarial and menial positions rather than in mainstream policing.

Pervasive sexism is reflected in the reference to police 'men' in all notices and training materials. The commonly heard sexual innuendoes and jokes in SAP circles do not create a welcoming atmosphere for women and may indeed discourage women from applying.

Similar comments apply to the under-representation of black people in management positions at all levels despite being in a majority at the lower levels of the organisation. Institutionalised racism undermines individual self esteem and alienates black police officers.

The dissatisfaction of these officers has several times been reflected during the period under review in marches organised by the Police and Prisons Civil Rights Union (POPCRU). We welcome the decision to allow the police to legally unionise and trust that the legitimate demands of POPCRU will be addressed.

Several progressive initiatives are indeed under way to prepare black police officers to take up senior positions. Affirmative action training programmes developed at the University of Witwatersrand through the Public and Development Management Executive Programme and by the Community Peace Foundation at the University of the Western Cape will accelerate the culture change programme by ensuring placement of suitably qualified black officers at key levels in the new SAP. 
These initiatives need to be accompanied by adequate support mechanisms and behavioural changes within the organisation so that new entrants are not marginalised or undermined.

It would be timely for the recently formed National Coalition on Gender and Policing Issues to develop and press for affirmative action schemes for women in the police.

\section{Children and Criminal Justice}

COMSA has been impressed by the work being carried out by Lawyers for Human Rights (LHR), an influential South African NGO, in obtaining legal representation and release from prison of young people.

However, the task of notifying the parent or guardian of an arrested child should be a matter of routine for the police. Their failure to do so has led to children as young as eight years old being unnecessarily remanded to prison.

We are aware that while some of the youth in jails are charged with serious crimes, the majority are charged with minor offences and could be released into the care of their parents. Such youth should not be in prison, where they are often exposed to worse crime, such as sexual assault and male rape which now appear commonplace in many secure establishments.

Whilst whipping has been removed from the statute books of most modern legal systems, it is still a commonly applied sentence for juveniles in South African courts. It is hoped that this practice will be abolished when the Chapter on Fundamental Rights in the Interim Constitution comes into force after the elections.

\section{Developing a Human Rights Culture in the Police}

In any society, police have extensive powers and responsibilities. They enjoy enormous discretionary powers. At the point of arrest and detention, an individual is potentially vulnerable, isolated from the rest of society and often not within view of a third party. Unless police are ethical, and exemplify high standards of personal conduct, they are likely to resort to force to obtain the information they need.

International standards provide illuminating and helpful guidance on police conduct to avoid this sort of eventuality.

Some of the most fundamental rights of individuals, enshrined in international human rights instruments, are of significance to the police service. These include the United Nations Declaration of Human Rights, the United Nations Code of Conduct for Law Enforcement Officials and United Nations Criminal Justice Standards for Peacekeeping Police.

Police are required, in terms of international standards, to uphold fundamental human rights, treating every person as an individual and displaying respect and compassion towards them. Every individual has a right to freedom 
of thought, conscience and religion, opinion and expression, peaceful assembly and association, to live in privacy and peace. Protecting individual rights also protects the rights of society.

The United Nations Universal Declaration of Human Rights refers to:

- non-discrimination

- the right to life, liberty and security

- the right not to be subjected to torture or to cruel, inhuman or degrading treatment

- recognition as a person before the law

- equal protection of the law

- a remedy when rights are violated

- not being subjected to arbitrary arrest or detention

- fair trial

- the presumption of innocence

- no retrospective legislation

- freedom from arbitrary interference with privacy

- the right not to be arbitrarily deprived of property

- freedom of thought, conscience and religion

- freedom of peaceful assembly and association.

Police powers are therefore subject to checks and balances. Police exist to maintain and sustain rights and freedom not detract from them. The pursuit of an offender acknowledges and respects the dignity, rights and freedoms of the victim. If police infringe the rights of the suspect, they diminish and compromise their own cause. Article Two of the UN Code of Conduct for Law Enforcement Officials states:

In the performance of their duty, Law Enforcement Officials shall respect and protect human dignity and maintain and uphold the human rights of all persons.

Similarly, police may not act against individuals who are not suspected of having committed an illegal act merely on the basis of their race, religion or political belief.

At the heart of human rights charters and laws is the principle that individuals are entitled to be treated with compassion and respect and it is essential to recognise the dignity of all. Police who breach these principles in democratic societies are answerable to the law.

Another important principle underpinning international policing is that of minimum force. Force may be exercised only when justified in order to effect an officer's lawful purpose and to restore the peace. In extreme cases, deadly force may be used. However, in the vast majority of cases, the UN Code of Conduct stresses that use of firearms should be kept to minimum. 
Community policing will only become a reality if police act with fairness, integrity and impartiality in carrying out their duties.

Fairness applies internally in the way individuals are recruited, selected, appraised, deployed, promoted and supported through equality initiatives and affirmative action. Fairness applies externally in ensuring non-discriminatory service provision.

Developing a human rights culture in the police will ensure that ordinary people who are given extraordinary powers behave in a professional and ethical way, both within the station and in their relations with the public.

There is already a considerable amount of training in civil liberties in South Africa. The challenge is for all members of the SAP and their local communities to work together to create a human rights culture of which everyone can be proud.

COMSA welcomes the steps already being taken by the SAP to address many of the issues covered in this Report. The rapid progress which has been made over the year that we have been in South Africa bodes well for the future. We offer every encouragement to the South African Police Service as it strives to become a democratic, consultative and professional service. 